\title{
PHOSPHORUS CRITICAL LEVELS AND AVAILABILITY IN LOWLAND SOILS CULTIVATED WITH FLOODED RICE
}

\author{
Isabela Orlando dos Santos Mariano ${ }^{1}$; Luiz Arnaldo Fernandes ${ }^{2 *}$; Valdemar Faquin ${ }^{1}$; Alex \\ Teixeira de Andrade ${ }^{1}$ \\ ${ }_{2}^{1}$ Depto.de Ciência do Solo - UFLA, C.P. 37 - CEP: 37200-000 - Lavras, MG. \\ ${ }^{2}$ Centro de Ciências Agrárias - UFMG, C.P. 135 - CEP: 39404-006- Montes Claros, MG. \\ ${ }^{*}$ Corresponding author <lafernand@ig.com.br>
}

\begin{abstract}
Lowland soils present a great potential for the flooded rice crop. This work aimed to estimate critical levels of $P$ in waterlogged soils cultivated with rice using Mehlich 1 and anion exchange resin as soil-P extractors, compare the performance of these extractors as for the evaluation of the $P$ availability, and study the soil-P fractions involved in the $P$ nutrition of the rice crop. Studied soils consisted of four Histosols: Low Humic Gley (GP), Aluvial (A), Humic Gley (GH) and Bog Soil (O) which were previously cultivated with beans. The experimental design was completely randomized, in a factorial scheme, using four soils, five $P$ rates $\left(75,150,300,500\right.$ and $800 \mathrm{mg} \mathrm{dm}^{-3}$ ) and two liming treatments (with and without liming), with three replicates. After 60 days of flooding, soil samples were submitted to $P$ extraction by Mehlich 1 and resin, and phosphorous fractionation. Two rice plants were cultivated in pots containing 3 $\mathrm{dm}^{3}$ of waterlogged soils. The labile $P$ and the moderately labile $P$ of the soils contributed for rice nutrition. The two tested extractors presented efficiency in the evaluation of $P$ availability for the rice cultivated in lowland waterlogged soils.
\end{abstract}

Key words: Oryza sativa, phosphorus fractions, extractors

\section{NÍVEIS CRÍTICOS E DISPONIBILIDADE DE FÓSFORO EM SOLOS CULTIVADOS COM ARROZ INUNDADO}

\begin{abstract}
RESUMO: Os solos de várzea apresentam-se com um grande potencial para o cultivo do arroz irrigado por inundação. No presente trabalho, objetivou-se estimar os níveis críticos de P pelos extratores Mehlich 1 e resina em solos de várzea cultivados com arroz sob inundação e identificar as frações de $P$ que estão contribuindo para a nutrição fosfatada do arroz. Foram utilizados quatro solos de várzea pré-cultivados com feijoeiro: Glei Pouco Húmico (GP), Aluvial (A), Glei Húmico (GH) e Orgânico (O). O experimento foi em delineamento inteiramente casualizado, em fatorial $4 \times 5 \times 2$ com três repetições, sendo: quatro solos, cinco doses de $P\left(75,150,300,500\right.$ e $\left.800 \mathrm{mg} \mathrm{dm}^{-3}\right)$ e dois níveis de calagem: ausência e presença. Após 60 dias de inundação, coletaram-se amostras dos solos para a determinação do $P$ por Mehlich 1 e resina e fracionamento de $P$. Cada parcela constituiu de um vaso de $3 \mathrm{dm}^{3}$ em que cultivaram-se duas plantas. As formas de $\mathrm{P}$ lábeis e pouco lábeis dos solos contribuíram para a nutrição fosfatada do arroz. Os dois extratores demonstraram eficiência na avaliação do P disponível para o arroz.

Palavras-chave: Oryza sativa, fração de fósforo, extratores
\end{abstract}

\section{INTRODUCTION}

Soil chemical analysis is the principal tool for soil fertility evaluation. The dose of fertilizer to be applied to the soil is mainly based on the diagnosis of the nutrient availability in the soil. A recent literature review has reported that phosphorous $(P)$ availability prediction has been extensively studied over the last decades (Silva \& Raij, 1999). However, it is not well known yet how methods are the most suitable for the evaluation of phosphorous availability in waterlogged soils.

Evaluation methods of $P$ availability for rice in drained soils have been tested for flooded rice in lowland soils. Among them, Mehlich 1 is the most available method for Minas Gerais State even if anion exchange resin (resin) is considered more promising in evaluating
P availability in flooded rice fields (Grande et al., 1986; Motta et al., 1994).

According to Motta et al. (1994) the P extraction from waterlogged soils by resin was less influenced by variations in organic matter contents and soil texture than by acid extractors. Grande et al. (1986) verified a high correlation between $\mathrm{P}$ taken up by flooded rice plants and amount of the nutrient extracted by resin, and a good correlation between Melhich 1 and $\mathrm{P}$ uptake by plants only in soils with less than $10 \%$ of organic matter.

Although waterlogged lowlands exploitation with agricultural activities endanger the ecosystem, there are not many information about amounts of $P$ to be applied seeking to avoid environmental impacts. $P$ dynamics in these soils are ever far too complex, because reactions of reduction and hydrolysis of other compounds (oxides and hydroxides) affect $\mathrm{P}$ contents in soil solution (Lindsay, 
1979). Hence, $P$ dynamics in flooded soils can be well described by approaching forms of $P$ in soils using method of fractionation (Hedley et al., 1982). The $P$ fractions of soils related to available $P$ by extractors, would allow the identification of the most extractable pool of $P$ for each soil, and then, the selection of the most efficient method for a particular area (Barbosa Filho et al., 1987). Obviously, the $P$ amounts obtained by extraction should be correlated to growth and total $P$ taken up by plants.

The objective of this work was to estimate critical levels of $P$ in four waterlogged soils cultivated with rice by extractors Melhich 1 and resin, compare the performance of these extractors as for the evaluation of the $P$ availability, and to find out which organic and inorganic forms of soil phosphorous contribute most to $P$ nutrition of rice in these systems.

\section{MATERIAL AND METHODS}

The experiment was carried out in a greenhouse at the Department of Soil Science at the Federal University of Lavras, using pots containing $3 \mathrm{dm}^{3}$ of each soil sample studied. Flooded rice plants (Oriza sativa L. cv. Jequitibá) were cultivated during the period October
1998- February 1999, in samples $(0-20 \mathrm{~cm})$ of four Histosols previously treated with $5 \mathrm{P}$ doses (Fernades et al., 2000) and with 2 liming levels (Faquin et al., 1998) and cultivated with beans plants.

Chemical, physical and mineralogical attributes of the natural samples of these soils are presented in Table 1.

The experiment with bean was carried out in $3 \mathrm{dm}^{-3}$ pots, greenhouse conditions. Pots were seeded with three plants, and one plant was harvested at the flowering period and the other two at the end of the cycle. Trials were set up in a completely randomized design. Treatments included all possible combinations among $4 \times 5 \times 2$ factorial four soils, five $P$ doses and 2 liming levels -liming and no liming $(n=4)$. The Bog Soil $(0)$ sample was artificially drained, showing lower rates of organic matter. Lime was applied to raise soil base saturation to $70 \%$, and consisted of a $\mathrm{CaO}(35 \%)+\mathrm{MgO}(14 \%)$ mixture, as recommended by Faquin et al. (1998).

Upon harvesting the bean plants, soils were air dried, passed through a $5 \mathrm{~mm}$ sieve, sampled, for chemical analysis and planted with flooded rice. Except for the number of replicates (3), trials were set up as described for the bean crop assay. Before flooding and sowing, soils were thoroughly mixed with macro and

Table 1 - Chemical, physical and mineralogical attributes of Low Humic Gley (GP), Aluvial (A), Humic Gley (GH), and Bog Soil (O).

\begin{tabular}{|c|c|c|c|c|c|c|c|c|c|c|c|c|c|}
\hline Soil & $\mathrm{pH}^{1}$ & $\mathrm{P}^{1}$ & $\mathrm{~K}^{1}$ & $\mathrm{Ca}^{1}$ & $\mathrm{Mg}^{1}$ & $\mathrm{Al}^{1}$ & $\mathrm{H}+\mathrm{Al}^{1}$ & $t^{1}$ & $\mathrm{~T}^{1}$ & $\mathrm{~m}^{1}$ & $\mathrm{~V}^{1}$ & PAMC $^{2}$ & $\mathrm{PR}^{2}$ \\
\hline & & \multicolumn{2}{|c|}{$\mathrm{mg} \mathrm{dm}^{-3}$} & \multicolumn{6}{|c|}{--o- } & \multicolumn{2}{|c|}{$--\%--$} & $\mathrm{mg} \mathrm{kg}^{-1}$ & $\mathrm{mg} \mathrm{L}^{-1}$ \\
\hline GP & 4.5 & 3 & 36 & 0.6 & 0.2 & 1.1 & 6.3 & 2.0 & 7.2 & 55 & 12 & 648 & 28 \\
\hline A & 4.7 & 3 & 103 & 2.7 & 1.1 & 0.2 & 4.5 & 4.3 & 8.6 & 5 & 47 & 689 & 27 \\
\hline $\mathrm{GH}$ & 4.7 & 8 & 51 & 0.7 & 0.2 & 1.6 & 13.7 & 2.6 & 14.7 & 61 & 7 & 2404 & 1.77 \\
\hline \multirow[t]{3}{*}{0} & 4.6 & 6 & 76 & 1.6 & 1.2 & 0.9 & 9.8 & 3.9 & 12.8 & 23 & 23 & 1051 & 16 \\
\hline & $\begin{array}{c}\text { Coarse } \\
\text { Sand }\end{array}$ & & $\begin{array}{l}\text { Fine } \\
\text { Sand }\end{array}$ & & Silt & & Clay & & $\begin{array}{l}\text { Organic } \\
\text { Matter }\end{array}$ & & $\begin{array}{c}\text { Bulk } \\
\text { Density }\end{array}$ & $\begin{array}{c}\text { Density of } \\
\text { particles }\end{array}$ & $\begin{array}{c}\text { Specific } \\
\text { surface } \\
\text { area }\end{array}$ \\
\hline & \multicolumn{10}{|c|}{ - } & $\mathrm{g} \mathrm{cm}^{-3}$ & & $\mathrm{~m}^{2} \mathrm{~g}^{-1}$ \\
\hline GP & 30 & & 611 & & 179 & & 180 & & 31 & & 1.0 & 2.7 & 121 \\
\hline A & 0 & & 179 & & 471 & & 350 & & 31 & & 0.8 & 2.8 & 137 \\
\hline $\mathrm{GH}$ & 10 & & 230 & & 390 & & 370 & & 230 & & 0.4 & 1.8 & 335 \\
\hline \multirow{3}{*}{$\mathrm{O}$} & 0 & & 120 & & 570 & & 310 & & 44 & & 0.6 & 2.1 & 181 \\
\hline & $\mathrm{SiO}_{2}{ }^{3}$ & & $\mathrm{Al}_{2} \mathrm{O}_{3}{ }^{3}$ & & $\mathrm{Fe}_{2} \mathrm{O}_{3}{ }^{3}$ & & $\mathrm{TiO}_{2}{ }^{3}$ & $\mathrm{P}_{2} \mathrm{O}_{5}{ }^{3}$ & $\mathrm{Fed}^{4}$ & $\mathrm{FeO}^{4}$ & $\mathrm{Feo} / \mathrm{Fe}_{\mathrm{d}}{ }^{5}$ & $\mathrm{~Gb}^{4}$ & $\mathrm{Ct}^{4}$ \\
\hline & \multicolumn{13}{|c|}{ 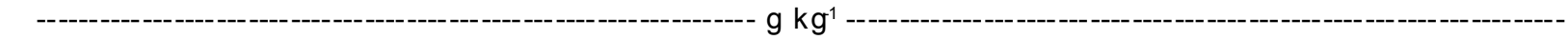 } \\
\hline GP & 84.2 & & 112.2 & & 13.0 & & 6.2 & 0.1 & 1.8 & 0.6 & 0.33 & 19 & 65 \\
\hline A & 209.3 & & 221.1 & & 74.5 & & 9.3 & 0.5 & 12.3 & 0.5 & 0.04 & 49 & 143 \\
\hline $\mathrm{GH}$ & 126.1 & & 175.5 & & 13.3 & & 5.5 & 1.5 & 2.3 & 0.6 & 0.26 & 53 & 48 \\
\hline 0 & 243.4 & & 247.1 & & 42.8 & & 7.3 & 0.5 & 5.3 & 0.5 & 0.09 & 57 & 121 \\
\hline
\end{tabular}

${ }^{1} \mathrm{pH}=\mathrm{pH}$ in water; $\mathrm{P}=$ phosphorous by Mehlich $1 ; \mathrm{K}=$ potassium; $\mathrm{Ca}=$ calcium; $\mathrm{Mg}=$ magnesium; $\mathrm{Al}=$ changeable aluminum; $\mathrm{H}+\mathrm{Al}$ $=$ changeable acidity; $\mathrm{t}=$ cationic exchange capacity at natural $\mathrm{pH} ; \mathrm{T}=$ cationic exchange capacity at $\mathrm{pH} 7.0 ; \mathrm{m}=\mathrm{Al}$ saturation $; \mathrm{V}=$ soil base saturation; physical attributes from EMBRAPA (1997)

${ }^{2} \mathrm{PR}=\mathrm{P}$ remaining e $\mathrm{PAMC}=\mathrm{P}$-adsorption maximum capacity (Alvarez V. and Fonseca, 1990)

${ }^{3}$ Sulfuric-extracted oxides (EMBRAPA, 1997);

${ }^{4} \mathrm{Fe}_{\mathrm{d}}=\mathrm{Fe}$ dithionite extractable; $\mathrm{Fe}_{\mathrm{o}}=\mathrm{Fe}$ oxalate extractable; $\mathrm{Ct}=$ kaolinite; $\mathrm{Gb}=$ gibbsite (Mehra \& Jackson, 1960)

${ }^{5} \mathrm{Fe}_{\mathrm{o}} / \mathrm{Fe}_{\mathrm{d}}=\mathrm{Fe}$ oxides' activity (Kämpf, 1988) 
micronutrients: $70 \mathrm{mg} \mathrm{N} \mathrm{dm}^{-3}$ as $\mathrm{NH}_{4} \mathrm{NO}_{3}, 100 \mathrm{mg} \mathrm{K} \mathrm{dm}^{-3}$ as $\mathrm{KNO}_{3}, 50 \mathrm{mg} \mathrm{S} \mathrm{dm}^{-3}$ as $\left(\mathrm{NH}_{4}\right)_{2} \mathrm{SO}_{4}, 0.5 \mathrm{mg} \mathrm{B} \mathrm{dm}^{-3}$ as $\mathrm{H}_{3} \mathrm{BO}_{3}, 0.75 \mathrm{mg} \mathrm{Cu} \mathrm{dm}{ }^{-3}$ as $\mathrm{CuSO}_{4} \cdot 5 \mathrm{H}_{2} \mathrm{O}$, and $2.5 \mathrm{Zn} \mathrm{N}$ $\mathrm{dm}^{-3} \mathrm{ZnSO}_{4} \cdot 7 \mathrm{H}_{2} \mathrm{O}$ (p.a. forms).

Soils were flooded for 60 days $(3 \mathrm{~cm}$ of water or the soil surface). Soil portions were then sampled $3 \mathrm{~cm}$ below the soil surface and evaluated through Mehlich 1 (EMBRAPA, 1997) and resin (Raij, et al., 1987) methods; chemical fractionation was done as proposed by Ivanoff et al. (1998) for Histosols: a sequential extraction of labile forms following the moderately labile and non-labile forms, but the moderately labile $P_{0}$ (fulvic acids) was not separated from the non-labile $P_{0}$ pool (humic acids) in the $\mathrm{NaOH}$ extract, as suggested by the authors.

Two $0.5-\mathrm{g}$ samples of dry soil were taken from each pot for $P$ fractionation. In one of the samples, $P$ associated with the soil live microbial biomass was estimated through chloroform $\left(\mathrm{CHCl}_{3}\right)$ fumigation (Hedley and Stewart, 1982). Total, labile $\mathrm{P}\left(\mathrm{P}_{\mathrm{i}}-\mathrm{NaHCO}_{3}+\mathrm{P}_{\text {。 }}\right.$ microbial) was determined according to Pavan \& Chaves (1996). The remaining soil was used for determination of succeeding fractions. On the other sample, only the extraction with $30 \mathrm{~mL}$ of $\mathrm{NaHCO}_{3}\left(0.5 \mathrm{~mol} \mathrm{~L}^{-1}\right)$ was applied after the determination of inorganic labile $P\left(P_{i}-\right.$ $\mathrm{NaHCO}_{3}$ ) in the extracts. The difference between the amounts of $\mathrm{P}-\mathrm{NaHCO}_{3}$ in the $\mathrm{CHCl}_{3}$-treated and untreated samples represents the $\mathrm{P}_{0}$ microbial, a significant portion of the readily bioavailable pool of $P$.

The organic and inorganic forms of $\mathrm{NaOH}-$ extractable $P$ were determined by adding $30 \mathrm{~mL}$ of $\mathrm{NaOH}$ $\left(0.5 \mathrm{~mol} \mathrm{~L}^{-1}\right)$ to the samples. Tubes were shaken for 16 hours and the $\mathrm{P}_{\mathrm{i}} \mathrm{-NaOH}$ was obtained in the extract. The extract was then autoclaved and $\mathrm{P}-\mathrm{NaOH}\left(\mathrm{P}_{\mathrm{i}}-\mathrm{NaOH}+\mathrm{P}_{0}-\right.$ $\mathrm{NaOH}$ ) was determined the amount of $\mathrm{P}_{0}-\mathrm{NaOH}$ was calculated as the difference between $\mathrm{P}-\mathrm{NaOH}$ and $\mathrm{P}_{\mathrm{i}}$ $\mathrm{NaOH}$. The remaining soil was used on the subsequent extraction.

The determination of $\mathrm{P}_{\mathrm{i}} \mathrm{-HCl}$ was done using 30 $\mathrm{mL}$ of $\mathrm{HCl}\left(1 \mathrm{~mol} \mathrm{~L}^{-1}\right)$. Samples were centrifuged at 7000 rpm for 15 minutes and $P$ was determined on the solution surface. The remaining soil was digested with $\mathrm{H}_{2} \mathrm{SO}_{4}(0.5$ mol L ${ }^{-1}$ ) and $\mathrm{H}_{2} \mathrm{O}_{2}$ to determine P-residual. The colorimetric method described by Murphy \& Rilley (1962) was used to determine $P$ in all extracts.

After fractionation, $\mathrm{P}$-forms were defined as: Labile $\mathrm{P}(\mathrm{LP})=\mathrm{P}_{\mathrm{i}}-\mathrm{NaHCO}_{3}+\mathrm{P}_{0}$ microbial; Moderately labile $P(M L P)=P_{i}-\mathrm{HCl}+P_{i}-\mathrm{NaOH}+P_{0}-\mathrm{NaOH}$; Non-labile $\mathrm{P}(\mathrm{NLP})=\mathrm{P}$-residual; and Total $\mathrm{P}(\mathrm{TP})=\mathrm{LP}+\mathrm{MLP}+$ NLP.

During the cultivation period, $\mathrm{N}$ and $\mathrm{K}$ were applied according to the species requirements. Treatments in which rice plants showed satisfactory development in each growth stage received $500 \mathrm{mg} \mathrm{N}$ $\mathrm{dm}^{-3}$ and $500 \mathrm{mg} \mathrm{K} \mathrm{dm}^{-3}$, split in 8 applications. Proportional doses were applied to the rest of the treatments, according to the growth of the plants.
At the end of the cycle, rice plants were harvested, oven-dried at $65-70^{\circ} \mathrm{C}$ and weighed. The dried shoot was ground to pass a $0.5-\mathrm{mm}$ sieve and $P$ was extracted as recommended by Malavolta et al. (1997). Grains were harvested, oven dried at $40-45^{\circ} \mathrm{C}$ until $13 \%$ moisture, cleaned, peeled and weighed. Phosphorus concentration in shoots, total $P$ taken up by plants and grain yield were measured.

Data were submitted to ANOVA and regression analysis. Regression equations were adjusted to the average grain yields as a function of $P$ rates utilized, and from these equations, the ins' physiological ripening and $P$ extracted from soils by the two extractors.

Correlation between $\mathrm{P}$-fractions in soils and $\mathrm{P}$ taken up by plants were estimated in order to identify the relationships between fractions of $P$ in the soils and $P$ nutrition of rice plants. Correlation between $\mathrm{P}$-fractions in soils and $P$ extracted by extractors Mehlich 1 and resin was calculated.

\section{RESULTS AND DISCUSSION}

\section{Phosphorus fractions in soils and phosphorus nutrition of rice}

Significant correlation was observed between $\mathrm{P}_{\text {- }}$ $\mathrm{NaHCO}_{3}, \mathrm{P}_{0}$-microbial and total labile $\mathrm{P}$ with the total $\mathrm{P}$ taken up by rice plants in soils with and without liming (Table 2). Both forms - $\mathrm{P}_{0}$-microbial (Brooke et al., 1984) and $\mathrm{P}_{\mathrm{i}}-\mathrm{NaHCO}_{3}$ (Bownan \& Cole, 1978; Tiessen et al., 1992) - are considered the main pools of available $P$ to plants.

In general, the fractions $\mathrm{P}_{0}-\mathrm{NaOH}, \mathrm{P}_{i}-\mathrm{NaOH}, \mathrm{P}_{i}-$ $\mathrm{HCl}$, total moderately labile $\mathrm{P},{ }^{\circ}$ and $\mathrm{P}$-total showed significant correlation with total plant $\mathrm{P}$, independently of liming rates (Table 2). The fractions $\mathrm{P}_{0}-\mathrm{NaOH}$ and total moderately labile $\mathrm{P}$ were not significantly correlated to the total plant $\mathrm{P}$ only in the limed $\mathrm{GH}$ soil conditions.

Ivanoff et al. (1998) suggested that humic acids represent the non-labile $P$ pool in soils while fulvic acids comprise the moderately labile $P$ 。 sources, which can become available to plants. Liming probably interfered in the distribution of organic (moderately labile) $\mathrm{P}$ pools in the $\mathrm{GH}$ soil.

All fractions of moderately labile $P$ were significantly correlated to $\mathrm{P}$ taken up by plants on nonlimed GH soil. Phosphorus fractions connected to amorphous or crystalline phosphates of $\mathrm{Fe}$ and $\mathrm{Al}$ which are considered of low availability to plants (Willians et al., 1980) can be $\mathrm{NaOH}$-extracted. The $\mathrm{P}_{\mathrm{i}}-\mathrm{HCl}$ is referred to the calcium phosphates (Walker \& Syers, 1976) made available in the long run through weathering in unfertilized soils of temperate regions (Smeck, 1985). However, in tropical acid, drained soils, this form of $P$ resulting from liming, is less stable than $P$ bound with $\mathrm{Fe}$ or $\mathrm{Al}$, and readily available to plants (Araújo et al., 1993). In reduced systems, $\mathrm{Fe}$ and Al phosphates are hydrolyzed by chelatants formed from anaerobic 
Table 2 - Pearson's correlation coefficients between total P taken up by plants and P forms in Low Humic Gley (GP), Aluvial $(\mathrm{A})$, Humic Gley $(\mathrm{GH})$ and Bog Soil $(\mathrm{O})$ soils.

\begin{tabular}{|c|c|c|c|c|c|}
\hline \multirow[b]{2}{*}{$P$ forms } & \multicolumn{5}{|c|}{ Soils } \\
\hline & $\mathrm{GH}$ & GP & 0 & A & All grouped \\
\hline \multicolumn{6}{|c|}{ With liming } \\
\hline $\mathrm{P}_{\mathrm{o}}$-microbial & $0.96^{* *}$ & $0.82^{*}$ & $0.99^{* *}$ & $0.98^{\star *}$ & $0.96^{* *}$ \\
\hline $\mathrm{P}_{\mathrm{i}}-\mathrm{NaHCO}_{3}$ & $0.92^{* *}$ & $0.86^{*}$ & $0.85^{\star}$ & $0.97^{\star *}$ & $0.95^{\star \star}$ \\
\hline labile P-total & $0.95^{\star *}$ & $0.87^{*}$ & $0.98^{* *}$ & $0.98^{* *}$ & $0.97^{* *}$ \\
\hline $\mathrm{P}_{0}-\mathrm{NaOH}$ & $-0.21 \mathrm{~ns}$ & $0.85^{*}$ & $0.94^{* *}$ & $0.89^{*}$ & $0.87^{*}$ \\
\hline $\mathrm{P}_{\mathrm{i}}-\mathrm{NaOH}$ & $0.89^{\star}$ & $0.91^{*}$ & $0.90^{*}$ & $0.89^{*}$ & $0.90^{*}$ \\
\hline $\mathrm{P}_{\mathrm{i}}-\mathrm{HCl}$ & $0.91^{*}$ & $0.86^{*}$ & $0.92^{*}$ & $0.91^{*}$ & $0.91^{*}$ \\
\hline Moderately labile P- total & $0.09 \mathrm{~ns}$ & $0.93^{* *}$ & $0.94^{* *}$ & $0.90^{*}$ & $0.87^{*}$ \\
\hline P-residual & $0.95^{* *}$ & $0.97^{* *}$ & $0.99^{* *}$ & $0.99^{* *}$ & $0.98^{* *}$ \\
\hline P- total & $0.87^{\star}$ & $0.92^{* *}$ & $0.98^{* *}$ & $0.97^{* *}$ & $0.96^{* \star}$ \\
\hline \multicolumn{6}{|c|}{ Without liming } \\
\hline $\mathrm{P}_{0}$-microbial & $0.97^{* *}$ & $0.93^{* *}$ & $0.80^{*}$ & $0.99^{* *}$ & $0.96^{* *}$ \\
\hline $\mathrm{P}_{\mathrm{i}}-\mathrm{NaHCO}_{3}$ & $0.93^{*}$ & $0.97^{* *}$ & $0.86^{*}$ & $0.99^{* *}$ & $0.97^{* *}$ \\
\hline labile P-total & $0.95^{\star *}$ & $0.98^{* *}$ & $0.89^{*}$ & $0.99^{* *}$ & $0.98^{* *}$ \\
\hline $\mathrm{P}_{0}-\mathrm{NaOH}$ & $0.94^{\star *}$ & $0.84^{*}$ & $0.84^{*}$ & $0.98^{\star *}$ & $0.95^{* *}$ \\
\hline $\mathrm{P}_{\mathrm{i}}-\mathrm{NaOH}$ & $0.94^{\star *}$ & $0.97^{* *}$ & $0.80^{*}$ & $0.94^{* *}$ & $0.96^{* *}$ \\
\hline $\mathrm{P}_{\mathrm{i}}-\mathrm{HCl}$ & $0.99^{* *}$ & $0.80^{*}$ & $0.92^{*}$ & $0.90^{*}$ & $0.88^{*}$ \\
\hline Moderately labile $\mathrm{P}$ - total & $0.96^{* *}$ & $0.96^{* *}$ & $0.81^{*}$ & $0.97^{\star *}$ & $0.97^{* *}$ \\
\hline P-residual & $0.99^{* *}$ & $0.95^{* *}$ & $0.99^{* *}$ & $0.97^{* *}$ & $0.98^{* *}$ \\
\hline P- total & $0.98^{* *}$ & $0.98^{\star *}$ & $0.86^{*}$ & $0.99^{* *}$ & $0.98^{* *}$ \\
\hline
\end{tabular}

${ }^{* *}$ significant at the 0.05 probability level; *significant at the 0.01 probability level; ns - non-significant.

decomposition of organic matter, and $P$ is released to the soil solution becoming available to the plants (Ponnamperuma, 1972). Subsequently, flooding breaks down calcium phosphate (Ponnamperuma, 1972) and increases $P$ diffusion in soils (Turner \& Gilliam, 1976). This is probably how moderately labile $\mathrm{P}$ (Ivannof et al., 1998 ) is made available to plants after flooding, enhancing $P$ supply to them.

Although the correlation between moderately labile $P$ forms and total $P$ taken up by plants was significant, there was no evidence that moderately labile $P$ was taken up by plants. Furthermore, the lag period between $P$ fertilization and rice cultivation may have not been long enough to establish this form in the soils.

The residual $P$-fraction represents the non-labile $P$ bound up with minerals structurally free from $P$ hematite, goethite, and gibbsite (Smeck, 1985). Phosphorus application leads to an increase on retention of $P$ in the soil by those minerals, contributing each time more to its occlusion. Concurrently, plants absorb more $\mathrm{P}$, and that might justify the high correlation observed between $\mathrm{P}$ taken up by plants and the residual $\mathrm{P}$ form on soils.

\section{Critical levels of $P$ in soils}

Regression equations were adjusted for values of $P$ extracted by Mehlich1 and resin extractors and the $P$ rates applied to each soil for each liming level
(Table 3). Critical levels of $P$ were estimated by Mehlich 1 and resin (Table 5 ) by substituting the $P$ rates respective to $90 \%$ of the maximum grain yield (Table 4 ) in these equations. The critical levels of $P$ evaluated with resin decreased as follows: $G P>G H>A>0$ without liming, and $\mathrm{GP}>\mathrm{A}>\mathrm{GH} \cong \mathrm{O}$ with liming. Working with 9 flooded soils, Mello (1991) reported a wide variation among critical levels of $P$, also depending on the type of extractor utilized to assess the $P$ status in the soils.

Independently of extractor and liming level, the highest values of $P$ critical levels were found for GP. These values are probably a consequence of the low phosphate buffering capacity observed for a large amount of PR and low values of PAMC in this soil (Table 1). In addition, GP soil has high $\mathrm{P}$-adsorption capacity in solution in reduced systems which is, confirmed by the high ratio $\mathrm{Fe}_{o} / \mathrm{Fe}_{d}$ (Table 1). Since this soil shows a low phosphate buffering capacity and a fast exhaustion of $P$ in solution, high concentrations of available $P$ is expected to be maintained in soil solution.

The literature shows that the $P$ availability to rice plants is related to the $P$ buffering capacity of soils (Hossner et al., 1973; Sanchez \& Smith, 1980; Moraes \& Dynia, 1992). Significant correlations between P critical levels by resin and $P$ remaining (PR) in limed soils were verified (Table 6 ), characterizing their $P$ buffering capacity (Muniz et al., 1985). 
Mello (1991) observed that critical soil levels of $\mathrm{P}$ extracted by Mehlich 1 are not highly correlated to soil attributes that express phosphate-buffering capacity, but this correlation is higher when anionic paper, which behaves similaCrly to the anion exchange resin, is used as extractor. According to Mello (1991), the extractor Mehlich 1 destroys part of the adsorption matrix - the low stability oxides. Nevertheless, these oxides remain intact during $\mathrm{P}$ adsorption analysis (i.e. $\mathrm{P}$ remainder or any other measure of $P$ buffering capacity). The amount of $P$ extracted by Mehlich 1 can differ among soils with equal buffering capacity but with different oxides stability. In fact, soils $A$ and GP, that showed different critical values of $P$

Table 3 - Regression equations of $P$-available by extractors $\left(Y=\mathrm{mg} \mathrm{dm}^{-3}\right)$, as dependent variable of $\mathrm{P}$ rates applied $\left(X=\mathrm{mg} \mathrm{dm}^{-3}\right)$ in the soils. Low Humic Gley (GP), Aluvial (A), Humic Gley (GH) and Bog Soil (O).

\begin{tabular}{|c|c|c|c|}
\hline Soil & Extractor & Equation & $\mathrm{R}^{2}$ \\
\hline \multicolumn{4}{|c|}{ With liming } \\
\hline \multirow{2}{*}{$\mathrm{GH}$} & Mehlich 1 & $Y=18.1382+0.2291^{* *} X$ & 0.96 \\
\hline & Resin & $Y=27.9765+0.1360^{*} X$ & 0.87 \\
\hline \multirow[t]{2}{*}{ GP } & Mehlich 1 & $Y=4.8315+0.3358^{* *} X$ & 0.99 \\
\hline & Resin & $Y=42.0047+0.3496^{* *} X$ & 0.97 \\
\hline \multirow[t]{2}{*}{$\mathrm{O}$} & Mehlich 1 & $Y=15.6334+0.2196^{* *} X$ & 0.99 \\
\hline & Resin & $Y=11.6535+0.1725^{* *} X$ & 0.94 \\
\hline \multirow[t]{2}{*}{ A } & Mehlich 1 & $Y=-8.1765+0.1627^{* *} X$ & 0.99 \\
\hline & Resin & $Y=-1.4371+0.3190^{* *} X$ & 0.99 \\
\hline \multicolumn{4}{|c|}{ Without liming } \\
\hline \multirow[t]{2}{*}{$\mathrm{GH}$} & Mehlich 1 & $Y=9.5811+0.2943{ }^{* *} X$ & 0.98 \\
\hline & Resin & $Y=35.209+0.1756^{* *} X$ & 0.99 \\
\hline \multirow[t]{2}{*}{ GP } & Mehlich 1 & $Y=35.3728+0.2960^{* *} X$ & 0.96 \\
\hline & Resin & $Y=78.0121+0.1397^{*} X$ & 0.84 \\
\hline \multirow[t]{2}{*}{$\mathrm{O}$} & Mehlich 1 & $Y=0.5822+0.2088^{* *} X$ & 0.99 \\
\hline & Resin & $Y=13.520+0.1843^{*} X$ & 0.99 \\
\hline \multirow[t]{2}{*}{ A } & Mehlich 1 & $Y=1.2580+0.0123^{* *} X$ & 0.99 \\
\hline & Resin & $Y=9.1571+0.1475^{* *} X$ & 0.96 \\
\hline
\end{tabular}

** significant at 0.01 probability level by t-test.

Table 4 - Maximum grain yield and $90 \%$ of the maximum production and $\mathrm{P}$ rates to reach these productions in the soils Low Humic Gley (GP), Aluvial (A), Humic Gley (GH) and Bog Soil (O).

\begin{tabular}{|c|c|c|c|c|}
\hline & \multicolumn{2}{|c|}{ GrainYield } & \multicolumn{2}{|c|}{$\mathrm{P}$ rates } \\
\hline Soil & $90 \%$ & Maximum & $90 \%$ & Maximum \\
\hline & \multicolumn{4}{|c|}{--------- g pot ${ }^{1}$--------- --------- $\mathrm{mg} \mathrm{dm}^{3}$------- } \\
\hline \multicolumn{5}{|c|}{ With liming } \\
\hline $\mathrm{GH}$ & 63.3 & 70.4 & 373 & 612 \\
\hline GP & 79.6 & 88.5 & 342 & 519 \\
\hline $\mathrm{O}$ & 86.0 & 95.5 & 390 & 609 \\
\hline A & 81.8 & 90.9 & 378 & 571 \\
\hline \multicolumn{5}{|c|}{ Without liming } \\
\hline $\mathrm{GH}$ & 50.8 & 56.4 & 361 & 634 \\
\hline GP & 45.6 & 50.7 & 336 & 623 \\
\hline 0 & 55.9 & 62.1 & 281 & 489 \\
\hline A & 86.6 & 96.3 & 398 & 622 \\
\hline
\end{tabular}

Scientia Agricola, v.59, n.1, p.113-120, jan./mar. 2002 established by Mehlich 1 (Table 5), were similar in their $\mathrm{P}$ buffering capacity, but differed regarding their stability of oxides (Table 1).

Except for the critical levels estimated by resin in treatments with liming (Table 7), positive, significant correlations between $\mathrm{P}$ critical levels and oxide activity $\left(\mathrm{Fe}_{\mathrm{o}} / \mathrm{Fe}_{\mathrm{d}}\right)$ were observed. Lime stabilizes $\mathrm{Fe}$ oxides in flooded systems (Mello, 1991) and increases the capacity of the soil to supply P to plants (Silva \& Raij, 1999). The high correlation between critical levels of $P$ extracted by resin in limed soils with $P$ buffering capacity (Table 6) supports the idea that the resin method identified these effects more effectively.

Resin is the only $\mathrm{P}$ extraction method that reveals adequately the liming effect on increasing $P$ availability to plants (Silva \& Raij, 1999). In general, the critical levels of $P$ in the treatments with and without liming were dependent on the Fe oxide activity when estimated with Mehlich 1 and also on the Fe oxide activity and $P$ remaining when measured by resin.

\section{$P$ availability by extractors Mehlich 1 and resin}

The liming $x$ soil $x P$ rate interaction altered $(P<0.01)$ the $P$ status evaluated by Mehlich 1 and resin. In general, the $P$ concentrations available by extractors decreased as follows: $\mathrm{GP}>\mathrm{GH}>\mathrm{O}>\mathrm{A}$, except for resin in limed soils, which showed a decrease in $P$ concentrations available by extractors as follows: $\mathrm{GP}>\mathrm{A}>\mathrm{GH}>\mathrm{O}$.

Table 5 - Estimated P critical levels in waterlogged soils to flooded rice, correspondent to $90 \%$ of the maximum production by extractors resin and Mehlich 1, in soils Low Humic Gley (GP), Aluvial (A), Humic Gley $(\mathrm{GH})$ and Bog Soil (O).

\begin{tabular}{|c|c|c|c|c|}
\hline & \multicolumn{4}{|c|}{ Extractors } \\
\hline \multirow[b]{2}{*}{ Soil } & \multicolumn{2}{|c|}{ With liming } & \multicolumn{2}{|c|}{ Without liming } \\
\hline & Mehlich 1 & Resin & Mehlich 1 & Resin \\
\hline & \multicolumn{4}{|c|}{ 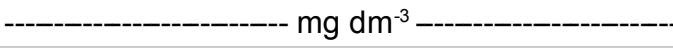 } \\
\hline $\mathrm{GH}$ & 103.75 & 78.77 & 115.95 & 98.76 \\
\hline GP & 119.81 & 161.71 & 134.76 & 124.93 \\
\hline $\mathrm{O}$ & 101.30 & 78.95 & 59.17 & 65.23 \\
\hline A & 53.35 & 119.21 & 50.22 & 67.82 \\
\hline
\end{tabular}

Table 6 - Pearson's correlation coefficients between P critical levels and P-remaining and $\mathrm{Fe}$ oxide activity $\left(\mathrm{Fe}_{\mathrm{o}} / \mathrm{Fe}_{\mathrm{d}}\right)$ in the studied waterlogged soils.

\begin{tabular}{llcl}
\hline Extractor & & Mehlich 1 & resin \\
\hline With liming & P-remainder & $0.18 \mathrm{~ns}$ & $0.99^{\star *}$ \\
& Fe oxides' activity & $0.83^{\star *}$ & $0.44 \mathrm{~ns}$ \\
Without liming & P-remainder & $0.47 \mathrm{~ns}$ & $0.67 \mathrm{~ns}$ \\
& Fe oxides' activity & $0.99^{* *}$ & $0.97^{* *}$ \\
\hline
\end{tabular}

** significant at the 0.05 probability level; *significant at the 0.01 probability level; ns - non-significant. 
Table 7 - Pearson's correlation coefficients between available P by extractors and forms of P in the studied waterlogged soils.

\begin{tabular}{|c|c|c|c|c|c|c|}
\hline \multirow[b]{2}{*}{$P$ forms } & \multicolumn{6}{|c|}{ Soils } \\
\hline & Extractors & $\mathrm{GH}$ & GP & $\mathrm{O}$ & $A$ & All grouped \\
\hline \multicolumn{7}{|c|}{ With liming } \\
\hline \multirow{2}{*}{$\mathrm{P}_{\mathrm{o}}$-microbial } & Mehlich 1 & $0.98^{* *}$ & $0.92^{* *}$ & $0.90^{*}$ & $0.98^{* *}$ & $0.96^{* *}$ \\
\hline & Resin & $0.88^{*}$ & $0.81^{*}$ & $0.78 \mathrm{~ns}$ & $0.98^{* *}$ & $0.93^{* *}$ \\
\hline \multirow[t]{2}{*}{$\mathrm{P}_{\mathrm{i}}-\mathrm{NaHCO}_{3}$} & Mehlich 1 & $0.93^{* *}$ & $0.93^{* *}$ & $0.98^{* *}$ & $0.98^{* *}$ & $0.97^{* *}$ \\
\hline & Resin & $0.97^{* *}$ & $0.90^{*}$ & $0.99^{*}$ & $0.99 * *$ & $0.97^{* *}$ \\
\hline \multirow[t]{2}{*}{ Labile P- total } & Mehlich 1 & $0.96^{* *}$ & $0.95^{\star *}$ & $0.99^{* *}$ & $0.98^{* *}$ & $0.98^{* *}$ \\
\hline & Resin & $0.97^{* *}$ & $0.90^{*}$ & $0.94^{* *}$ & $0.99^{* *}$ & $0.97^{* *}$ \\
\hline \multirow[t]{2}{*}{$\mathrm{P}_{0}-\mathrm{NaOH}$} & Mehlich 1 & $-0.21 n s$ & $0.94^{* *}$ & $0.97^{* *}$ & $0.90^{*}$ & $0.92^{* *}$ \\
\hline & Resin & $-0.14 n s$ & $0.87^{*}$ & $0.97^{* *}$ & $0.91^{*}$ & $0.92^{* *}$ \\
\hline \multirow[t]{2}{*}{$\mathrm{P}_{\mathrm{i}}-\mathrm{NaOH}$} & Mehlich 1 & $0.93^{* *}$ & $0.91^{* *}$ & $0.93^{* *}$ & $0.92^{*}$ & $0.93^{* *}$ \\
\hline & Resin & $0.83^{*}$ & $0.86^{*}$ & $0.85^{\star}$ & $0.92^{* *}$ & $0.91^{* *}$ \\
\hline \multirow[t]{2}{*}{$\mathrm{P}_{\mathrm{i}}-\mathrm{HCl}$} & Mehlich 1 & $0.93^{* *}$ & $0.94^{* *}$ & $0.96^{* *}$ & $0.91^{*}$ & $0.95^{* *}$ \\
\hline & Resina & $0.74 \mathrm{~ns}$ & $0.88^{*}$ & $0.88^{*}$ & $0.91^{*}$ & $0.89^{*}$ \\
\hline \multirow[t]{2}{*}{ Moderately labile $\mathrm{P}$ - total } & Mehlich 1 & $0.17 n s$ & $0.97^{* *}$ & $0.97^{* *}$ & $0.91^{*}$ & $0.92^{* *}$ \\
\hline & Resin & $0.54 \mathrm{~ns}$ & $0.91^{*}$ & $0.88^{*}$ & $0.91^{*}$ & $0.91^{* *}$ \\
\hline \multirow[t]{2}{*}{ P-residual } & Mehlich 1 & $0.96^{* *}$ & $0.99^{* *}$ & $0.99^{* *}$ & $0.99^{* *}$ & $0.99^{*}$ \\
\hline & Resin & $0.80^{*}$ & $0.98^{* *}$ & $0.98^{* *}$ & $0.99^{* *}$ & $0.97^{* *}$ \\
\hline \multirow[t]{2}{*}{ P-total } & Mehlich 1 & $0.91^{*}$ & $0.98^{* *}$ & $0.99^{* *}$ & $0.97^{* *}$ & $0.98^{*}$ \\
\hline & Resin & $0.96^{* *}$ & $0.93^{* *}$ & $0.94^{* *}$ & $0.98^{* *}$ & $0.97^{* *}$ \\
\hline \multicolumn{7}{|c|}{ Without liming } \\
\hline \multirow[t]{2}{*}{$P_{0}$-microbial } & Mehlich 1 & $0.95^{* *}$ & $0.83^{*}$ & $0.87^{*}$ & $0.99 * *$ & $0.93^{* *}$ \\
\hline & Resin & $0.98^{* *}$ & $0.97^{* *}$ & $0.81^{*}$ & $0.97^{* *}$ & $0.98^{* *}$ \\
\hline \multirow[t]{2}{*}{$\mathrm{P}_{\mathrm{i}}-\mathrm{NaHCO}^{3}$} & Mehlich 1 & $0.93^{* *}$ & $0.96^{* *}$ & $0.97^{* *}$ & $0.99^{* *}$ & $0.98^{* *}$ \\
\hline & Resin & $0.93^{* *}$ & $0.84^{*}$ & $0.98^{* *}$ & $0.98^{* *}$ & $0.97^{* *}$ \\
\hline \multirow[t]{2}{*}{ Labile P- total } & Mehlich 1 & $0.97^{* *}$ & $0.94^{* *}$ & $0.96^{* *}$ & $0.99^{* *}$ & $0.99^{* *}$ \\
\hline & Resin & $0.96^{* *}$ & $0.94^{* *}$ & $0.98^{* *}$ & $0.98^{* *}$ & $0.98^{* *}$ \\
\hline \multirow[t]{2}{*}{$\mathrm{P}_{0}-\mathrm{NaOH}$} & Mehlich 1 & $0.96^{* *}$ & $0.66 \mathrm{~ns}$ & $0.99^{* *}$ & $0.94^{* *}$ & $0.93^{* *}$ \\
\hline & Resin & $0.93^{* *}$ & $0.96^{* *}$ & $0.99^{* *}$ & $0.94^{* *}$ & $0.97^{*}$ \\
\hline \multirow[t]{2}{*}{$\mathrm{P}_{\mathrm{i}}-\mathrm{NaOH}$} & Mehlich 1 & $0.94^{* *}$ & $0.83^{*}$ & $0.98^{* *}$ & $0.91^{*}$ & $0.97^{*}$ \\
\hline & Resin & $0.95^{* *}$ & $0.90^{*}$ & $0.97^{\star *}$ & $0.87^{*}$ & $0.95^{*}$ \\
\hline \multirow[t]{2}{*}{$\mathrm{P}_{\mathrm{i}}-\mathrm{HCl}$} & Mehlich 1 & $0.97^{* *}$ & $0.90^{* *}$ & $0.96^{* *}$ & $0.82^{*}$ & $0.97^{* *}$ \\
\hline & Resin & $0.99^{* *}$ & $0.75 \mathrm{~ns}$ & $0.98^{* *}$ & $0.84^{*}$ & $0.94^{* *}$ \\
\hline \multirow[t]{2}{*}{ Moderately labile $\mathrm{P}$ - total } & Mehlich 1 & $0.96^{* *}$ & $0.83^{*}$ & $0.99^{* *}$ & $0.92^{* *}$ & $0.97^{* *}$ \\
\hline & Resin & $0.96^{* *}$ & $0.83^{*}$ & $0.98^{* *}$ & $0.92^{*}$ & $0.97^{* *}$ \\
\hline \multirow[t]{2}{*}{ P-residual } & Mehlich 1 & $0.98^{* *}$ & $0.90^{*}$ & $0.99^{* *}$ & $0.99^{* *}$ & $0.99^{* *}$ \\
\hline & Resin & $0.99^{* *}$ & $0.90^{* *}$ & $0.99^{* *}$ & $0.97^{* *}$ & $0.98^{* *}$ \\
\hline \multirow[t]{2}{*}{ P-total } & Mehlich 1 & $0.97^{* *}$ & $0.92^{* *}$ & $0.98^{* *}$ & $0.98^{* *}$ & $0.99^{* *}$ \\
\hline & Resin & $0.99^{* *}$ & $0.92^{* *}$ & $0.98^{* *}$ & $0.97^{* *}$ & $0.98^{* *}$ \\
\hline
\end{tabular}

**significant at the 0.05 probability level ; *significant at the 0.01 probability level; ns - non-significant.

Except for $\mathrm{GH}$ soil with and without lime, and $\mathrm{O}$ soil with lime, resin extracted more $P$ than Mehlich 1. The $\mathrm{GH}$ soil contained high amounts of organic matter and total $P$, suggesting a contribution of organic $P$ to the values found with the acid extractor. Mehlich 1 can extract relatively high amounts of $P$ in soils with high organic matter contents $(>10 \%)$, with $P_{0}$ forms, not available to plants, apparently included (Grande et al., 1986).
However, the high correlation between $\mathrm{P}_{0}$ microbial (labile) and $\mathrm{P}$ extracted by Mehlich 1 as well as the very low correlation between Mehlich 1 and $\mathrm{P}_{0}-\mathrm{NaOH}$ (moderately labile) suggest that Melhich 1 extracted only available organic forms of $\mathrm{P}$ off the $\mathrm{GH}$ soil. The $\mathrm{P}_{0}-\mathrm{NaOH}$ fraction did not show correlation with $\mathrm{P}$ extracted by either Mehlich 1 or resin, as did the total moderately labile $\mathrm{P}$ (Table 7). 
$P_{0}$ microbial is one of the most important $P$ forms in plant nutrition (Brooke et al., 1984) showing the highest correlation with total $P$ taken up by plants (Table 2). In the limed $\mathrm{O}$ soil, $\mathrm{P}$ extracted by resin was not correlated with this form, meaning that the principle of the resin method (the transference of labile $P$ from soil to resin by anionic exchange) showed efficiency only for the labile inorganic $\mathrm{P}$ form of limed $\mathrm{O}$ soil, as confirmed by the high correlation between $\mathrm{P}$ extracted and $\mathrm{P}_{\mathrm{i}}-\mathrm{NaHCO}_{3}$ (Table 7).

Both extractors were similar in their ability to extract $P$ fractions from all soil groups (Table 7 ). Research has demonstrated that Mehlich 1 has been somewhat inefficient in predicting $P$ availability to flooded rice in lowland soils (Grande et al., 1986), probably because there is a predominance of $\mathrm{P}-\mathrm{Fe}$ in these soils (Mahapatra \& Patrick, 1969), and acid extractors extract preferentially P-Ca (Raij, 1991). However, researchers who studied the relationship between available and inorganic $P$ fractions, have reported that Mehlich 1 predominantly extracted $P$ from $\mathrm{P}-\mathrm{Fe}$ in Latosols, recommending the use of this extractor for soils with predominance of P-Fe (Barbosa Filho et al., 1987).

Phosphorus extracted either by resin or by Mehlich 1 had positive correlation with total $P$ taken up by plants for each soil and for all, grouped, limed or nonlimed soils (Table 8). Considering the relations between $\mathrm{P}$ extracted by Mehlich 1 and resin with labile $\mathrm{P}$ (Table 7 ), and total $P$ taken up in shoot (Table 8), it can be concluded that both Mehlich 1 and resin methods were efficient in the evaluation of $P$ availability to flooded rice in the soils studied.

Grande et al. (1986) referred to resin as an effective and to Mehlich 1 as a non-effective method for prediction of availability of $\mathrm{P}$ to flooded rice. The authors consider that clay contents, organic matter, and total $P$ discreetly influence resin extraction, suggesting that resin detects almost all labile $P$ availability to rice in waterlogged soils. Motta et al. (1994) also reported resin as not only the most efficient method to evaluate $P$

Table 8 - Pearson's correlation coefficients between available $P$ by extractors and $P$ taken up in shoot in the waterlogged soils studied.

\begin{tabular}{lcccc}
\hline \multicolumn{4}{c}{ Extractors } \\
\hline Soils & Mehlich 1 & Resin & Mehlich 1 & Resin \\
GH & $0.99^{* *}$ & $0.83^{*}$ & $0.98^{* *}$ & $0.99^{* *}$ \\
GP & $0.97^{* *}$ & $0.99^{* *}$ & $0.92^{* *}$ & $0.93^{* *}$ \\
O & $0.99^{* *}$ & $0.99^{* *}$ & $0.81^{*}$ & $0.88^{*}$ \\
A & $0.98^{* *}$ & $0.98^{* *}$ & $0.98^{* *}$ & $0.98^{* *}$ \\
All & $0.99^{* *}$ & $0.98^{* *}$ & $0.94^{* *}$ & $0.99^{* *}$ \\
grouped & & & & \\
\hline
\end{tabular}

** significant at the 0.05 probability level; *significant at the 0.01 probability level; ns - non-significant. availability to plants in lowland, waterlogged soils, but also a method that is less influenced by variations in organic matter content and soil texture than acid extractors.

\section{CONCLUSIONS}

Both labile $\mathrm{P}$ forms and moderately labile $\mathrm{P}$ forms may be contributing to the $P$ nutrition of rice in the studied Histosols. The critical levels of $P$ estimated by Melhich 1 were: $104\left(\mathrm{mg} \mathrm{P} \mathrm{dm}^{-3}\right)(\mathrm{GH}), 120\left(\mathrm{mg} \mathrm{P} \mathrm{dm}^{-3}\right)(\mathrm{GP}), 101$ $\left(\mathrm{mg} \mathrm{P} \mathrm{dm}^{-3}\right)(\mathrm{O})$, and $53\left(\mathrm{mg} \mathrm{P} \mathrm{dm}^{-3}\right)(\mathrm{A})$, with liming; and $116(\mathrm{GH}), 135(\mathrm{GP}), 59(\mathrm{O})$, and $50(\mathrm{~A})$ without liming. When estimated by resin, critical levels of $P$ were $(\mathrm{mg} P$ $\mathrm{dm}^{-3}$ ): $79(\mathrm{GH}), 162(\mathrm{GP}), 79(\mathrm{O})$ and $119(\mathrm{~A})$ with liming; and $99(\mathrm{GH}), 125(\mathrm{GP}), 65(\mathrm{O})$, and $68(\mathrm{~A})$ without liming. Mehlich 1 and resin extraction methods were similar in the extraction of $P$ fractions from soils, specially in the evaluation of $P$ availability to flooded rice in the studied Histosols.

\section{REFERENCES}

ALVAREZ V.V.H.; FONSECA, D.B. da. Definição de doses de fósforo para determinação da capacidade máxima de adsorção de fosfatos e para ensaios em casa de vegetação. Revista Brasileira de Ciência do Solo, v.14, p.49-55.1990.

ARAÚJO, M.S.B.; SALCEDO, L.H.; SAMPAIO, V.S.B. Efeito de fertilizações fosfatadas anuais em solo cultivado com cana de açúcar. I. intensidade e formas de acumulação. Revista Brasileira de Ciência do Solo, v.17, p.389-396, 1993.

BARBOSA FILHO, M.; KINJO, T.; MURAOKA, T. Relações entre fósforo "extraível", frações inorgânicas de fósforo e crescimento do arroz em função de fontes de fósforo, calagem e tempo de incubação. Revista Brasileira de Ciência do Solo, v.11, p.147-155, 1987.

BOWMAN, R.A.; COLE, C.V. Transformations of organic phosphorus substrates in soil are evaluated by $\mathrm{NaHCO}_{3}$ extraction. Soil Science, v.125, p.49-54, 1978.

BROOKE, P.C.; POWSON, D.S.; JENKINDON, D.S. Phosphorus in the soil microbial biomass. Soil Biology and Biochemistry, v.16, p.169-175, 1984.

EMPRESA BRASILEIRA DE PESQUISA AGROPECUÁRIA. Serviço Nacional de Levantamento e Conservação de Solo. Manual de métodos de análise de solo. Rio de Janeiro: EMBRAPA, SNLCS, 1997. 212p.

FAQUIN, V.; ANDRADE, C.A.B.; FURTINI NETO, A.E.; ANDRADE, A.T.; CURI, N. Resposta do feijoeiro à aplicação de calcário em solos de várzea do sul de Minas Gerais. Revista Brasileira de Ciência do Solo, v.22, p.651-660, 1998.

FERNANDES, L.A.; FAQUIN, V.; FURTINI NETO, A.E.; CURI, $\mathrm{N}$. Frações de fósforo e atividade da fosfatase ácida em plantas de feijoeiro cultivadas em solos de várzea. Revista Brasileira de Ciência do Solo, v.24, p.561-571, 2000.

FORNASIERI FILHO, D.; FORNASIERI, J.L. Manual da cultura do arroz. Jaboticabal: FUNEP, 1993. $221 \mathrm{p}$.

GRANDE, M.A.; CURI, N.; QUAGGIO, J.A. Disponibilidade de fósforo pelos extratores de Mehlich e resina, em solos cultivados com arroz irrigado. Revista Brasileira de Ciência do Solo, v.10, p.45-50, 1986.

HEDLEY, M.J.; STEWARD, W.B. A method to measure microbial phosphate in soils. Soil Biology and Biochemistry, v.14, p.377-385, 1982 
HEDLEY, M.J.; STEWARD, W.B.; CHAUHAN, B.S. Changes in inorganic and organic soil phosphorus fraction induced by cultivation pratices and laboratory incubation. Soil Science Society of America Journal, v.46, p.970-976, 1982.

HOSSNER, L.R.; FREEOUF, J.A.; FELSOM, B.L. Solution phosphorous concentration and growth of rice (Oryza sativa L.) in flooded soils. Soil Science Society of America Proceedings, v.37, p.405-408, 1973.

IVANOFF, D.B.; REDDY, R.; ROBINSON, S. Chemical fractionation of organic phosphorus in selected histosols. Soil Science, v.163, p.36-45, 1998.

KAMPF, N. O ferro no solo. In: REUNIÃO SOBRE FERRO EM SOLOS INUNDADOS, 1., Goiânia, 1988. Anais. Goiânia: EMBRAPA, CNPAF, 1988. p.35-71. (Documentos, 22)

LINDSAY, W.L. Chemical equilibria in soils. New York: John Willey, 1979. 449p.

MAHAPATRA, I.C.; PATRICK, W.H. Inorganic phosphate transformation in waterlooged soils. Soil Science, v.107, p.281-288, 1969.

MALAVOLTA, E.; VITTI, G.C.; OLIVEIRA, S.A. Avaliação do estado nutricional das plantas: princípios e aplicações. Piracicaba: Associação Brasileira para Pesquisa da Potassa e do Fosfato, 1997. 210p.

MELLO, J.W.V. Dinâmica de fósforo, ferro e manganês e disponibilidade de fósforo para o arroz em solos inundados. Viçosa, 1991. 212p. Tese (Doutorado) - Universidade Federal de Viçosa.

MEHRA, O.P.; JACKSON, N.L. Iron oxide removal from soils and clays by a dithionite-citrate system buffered with sodium bicarbonate. Clays and Clay Minerals, v.3, p.317-327, 1960.

MORAES, J.F.V.; DYNIA, J.F. Alterações nas características químicas e físico-químicas de um solo Gley Pouco Húmico sob inundação e após a drenagem. Pesquisa Agropecuária Brasileira, v.27, p.223-235, 1992.

MOTTA, A.C.V.; CARVALHO, J.G.; GUEDES, G.A.A.; CURI, N. Comparação entre métodos para avaliação da disponibilidade de fósforo em solos de várzea do estado de Minas Gerais. Ciência e Prática, v.18, p.349-356, out/dez. 1994.

MUNIZ, A.S.; NOVAIS, R.F.; BARROS, N. F.; NEVES, J.C.L. Níveis críticos de fósforo na parte aérea da soja como variável do fator capacidade de fósforo do solo. Revista Brasileira de Ciência do Solo, v.9, p.237-243, 1985.
MURPHY, J.; RILEY, J.P. A modified single solution method for the determination of phosphate in natural waters. Analytica Chimica Acta, v.27, p.31-36, 1962.

PAVAN, M.A.; CHAVES, J.C.D. Alterações nas frações de fósforo no solo associadas com a densidade populacional de cafeeiros. Revista Brasileira de Ciência do Solo, v.20, p.251256, 1996.

PONNAMPERUMA, F.N. The chemistry of submerged soils. Advances in Agronomy, v.24, p.28-96, 1972.

RAIJ, B. van. Fertilidade do solo e adubação. Piracicaba: POTAFOS, 1991, 343p.

RAIJ, B. van.; QUAGGIO, J.A.; CANTARELLA, H.; FERREIRA, M.E.; LOPES, A.S.; BATAGLIA, O.C. Análise química do solo para fins de fertilidade. Campinas: Fundação Cargil, 1987. 170p

SANCHES, P.A.; SMITH, T.J. Níveis críticos de fósforo para arroz de sequeiro em um latossolo dos cerrados. Revista Brasileira de Ciência dos Solos, v.4, p.88-92, 1980.

SILVA, F.C., RAIJ, B. van. Disponibilidade de fósforo em solos avaliada por diferentes extratores. Pesquisa Agropecuária Brasileira, v.34, p.267-288, 1999.

SMECK, N.E. Phosphorus dynamics in soils and landscapes. Geoderma, v.36, p.185-199, 1985.

TIESSEN, H.; SALCEDO, I.H.; SAMPAIO, E.V.S.B. Nutrients and soil organic matter dynamics under shifting cultivation in semiarid northeastern Brazil. Ecosystems and Enviroments, v.38, p.139-159, 1992.

TURNER, F.T.; GILLIAN, J.W. Increased P diffusion as an explanation of increased $P$ availability in flooded rice soils. Plant and Soil, v.45, p.365-377, 1976.

WALKER, T.W.; SYERS, J.K. The fate of phosphorus during pedogenesis. Geoderma, v.15, p.1-19, 1976.

WILLIAMS, J.D.H.; MAYER, T.; NRIAGU, J.O. Extractability of phosphate minerals common in soils and sediments. Soil Science Society of American Journal, v.44, p.462-465, 1980.

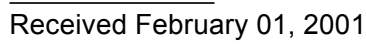

